\title{
Thermal properties of polypropylene and high modulus polyethylene fibers reinforced concretes
}

\section{Propriedades térmicas do concreto reforçado com fibras de polipropileno e polietileno de alto módulo}

\author{
J. C. AMARAL JR \\ josueamaralir@gmail.com \\ https://orcid.org/0000-0002-0032-000X \\ W. G. MORAVIA \\ weber.moravia@cefetmg.br \\ https://orcid.org/0000-0001-5968-9226
}

\begin{abstract}
Concrete is one of the materials most used by the construction industry. Reinforcing this material with fibers is a technique used to improve its mechanical properties. Steel and polymer fibers are the main types used in this application and there are few studies about the influence of polymer fibers on the thermal properties of concrete. In order to analyze this influence, the present work carried out thermal conductivity, thermal expansion, and compressive strength after exposure to a temperature of $200{ }^{\circ} \mathrm{C}$ on specimens made of concrete with addition of polypropylene (PP) fibers and concrete with addition of high modulus polyethylene (HMPE). It was also conducted thermogravimetric analysis (TGA) on PP and HMPE fibers. The results show that the addition of polymer fibers alters the thermal properties of the concrete, reducing its thermal expansion, for example.
\end{abstract}

Keywords: thermal properties, concrete, fiber reinforced concrete, polymers.

\section{Resumo}

O concreto é um dos materiais mais utilizados pela indústria da construção civil. Reforçar esse material com fibras é uma técnica utilizada para aprimorar suas propriedades mecânicas. Fibras de aço e polímeros são os principais tipos utilizados nessa aplicação e existem poucos estudos a respeito da influência das fibras poliméricas nas propriedades térmicas do concreto. Com o objetivo de analisar tal influência, o presente trabalho realizou ensaios de condutividade térmica, dilatação térmica e resistência à compressão após exposição à temperaturas de $200{ }^{\circ} \mathrm{C}$ em corpos de prova confeccionados com concreto com adição de fibras de polipropileno (PP) e concreto com adição de fibras de polietileno de alto módulo (PEAM). Também foram conduzidos ensaios de análise termogravimétrica (ATG) nas fibras de PP e PEAM. Os resultados mostram que a adição de fibras poliméricas alteram as propriedades térmicas do concreto, reduzindo sua dilatação térmica, por exemplo.

Palavras-chave: propriedades térmicas, concreto, concreto reforçado com fibras, polímeros. 


\section{Introduction}

Concrete is a composite material with typical characteristics of ceramic materials, meaning high compressive strength but low ductility and tensile strength. It usually consists of a cement paste, which surrounds the fine and coarse aggregates [1]. This material is widely applied in the construction industry, but for many applications, it is needed to improve the tensile strength, which is usually made by the insertion of steel bars [2]. Another way to improve concrete's tensile strength is through the addition of fibers. This type of reinforcement gained much market and researchers attention starting from the $60 \mathrm{~s}$. The main role of those fibers in the concrete is to reduce the formation of cracks and reduce its opening [3]. Most of the fibers used to reinforce concrete are made of steel, and this type of fibers are widely studied $[3,4,5,6]$. Polymeric (PP) fibers are also used, usually made of polypropylene, and the mechanical properties of concrete reinforce with PP fibers are extensively studied [5, 7, 8, 9]. Some recent works have studied how adding fibers to concrete affects its behavior when exposed to a high-temperature environment, such as building fire, where the temperature could range from 200 ${ }^{\circ} \mathrm{C}$ to more than $1000{ }^{\circ} \mathrm{C}[11,12]$.

High modulus polyethylene (HMPE) is a high-performance polymer, with tensile strength around $3000 \mathrm{MPa}$ and elasticity modulus between 109 and $132 \mathrm{GPa}$ [10]. Due to its high tensile strength and low density, HMPE has been used as mooring ropes in offshore oil and gas industries $[13,14]$. Usually, most limitations to HMPE applications comes from its poor creep behavior. Some recently developed types of HMPE have addressed this issue, resulting in a material with lower creep deformation, such as Dyneema ${ }^{\circledR}$ (DMS)
[13]. To this date, most applications of HMPE fibers are limited to mooring and lifting ropes. It was not found any studied using HMPE fibers as concrete reinforcement.

\section{Materials and experimental program}

The reference concrete used in this work was made using high early strength cement (CAUE CP-V ARI, InterCement Brasil), medium size sand, crushed limestone, potable water. Table 1 presents some characteristic values of the aggregates, and Table 2 presents the physical characteristics of the cement. Cement Fineness and sand fineness modulus are values associated with the granulometry of these materials. PP fibers (Fiberlock $®$, Etruria) and HMPE fibers (Dyneema ${ }^{\circledR}, D M S$ ) were used as fiber reinforcement

The ratio of materials was designed for concrete with characteristic strength (fck) of $25 \mathrm{MPa}$. In the PP and HMPE fiber reinforced concrete samples, the quantity (volume) of fiber added was equal to 1 $\%$ of the sample volume. Table 3 shows the proportions of materials used for each type of concrete studied. The concrete and fiber reinforced concrete density was estimated to be around $2.35 \mathrm{~g} / \mathrm{cm}^{3}$. The concrete and fiber reinforced concrete samples were mixed using an electric concrete mixer with 20 liters capacity. The procedure for making and curing all samples followed the standard practice describes in ASTM C192/C192M, with a few modifications in regards to the difficulties due to adding polymeric fibers to the mixture. Most modifications were related to the elimination of air bubbles inside the samples. For that, after pouring a layer of concrete inside the mold, an iron bar was used to compress the mixture. In sequence, the filled mold was put in a vibration table

\section{Table 1}

Physical characteristics of the cement CP-V

\begin{tabular}{|c|c|c|c|}
\hline \multicolumn{4}{|c|}{ Cement CP-V physical characteristics } \\
\hline $\begin{array}{l}\text { Specific mass } \\
\left(\mathrm{g} / \mathrm{cm}^{3}\right)\end{array}$ & $\begin{array}{c}\text { Fineness - no. } 200 \text { sieve } \\
(\%)\end{array}$ & $\begin{array}{l}\text { Initial/Final setting time } \\
\text { (min) }\end{array}$ & Chemical composition \\
\hline 3.26 & 2.00 & $160 / 240$ & $\begin{array}{c}\mathrm{CaO}(67.1 \%), \mathrm{SiO}(19.3 \%), \\
\mathrm{Al}_{2} \mathrm{O}_{3}(3.1 \%), \mathrm{Fe}_{2} \mathrm{O}_{3}(2.6 \%), \\
\mathrm{P}_{2} \mathrm{O}_{5}(1.1 \%), \operatorname{PPC}(3.3 \%) \\
\text { and others }(3.5 \%)\end{array}$ \\
\hline
\end{tabular}

\section{Table 2}

Physical characteristics of the aggregates

\begin{tabular}{ccc}
\hline Parameter & Sand & Crushed limestone \\
\hline Specific mass $\left(\mathrm{g} / \mathrm{cm}^{3}\right)$ & 2.58 & 2.68 \\
Unitary mass $\left(\mathrm{g} / \mathrm{cm}^{3}\right)$ & 1.40 & 1.64 \\
Fineness modulus & 2.18 & 6.48 \\
Maximum characteristic dimension $(\mathrm{mm})$ & - & 19.00 \\
\hline
\end{tabular}

\section{Table 3}

Proportions of materials used

\begin{tabular}{cccccc}
\hline $\begin{array}{c}\text { Concrete } \\
\text { composition }\end{array}$ & $\begin{array}{c}\text { Cement } \\
(\mathrm{g})\end{array}$ & $\begin{array}{c}\text { Fine aggregate } \\
(\mathrm{g})\end{array}$ & $\begin{array}{c}\text { Coarse aggregate } \\
(\mathrm{g})\end{array}$ & $\begin{array}{c}\text { Water } \\
(\mathrm{g})\end{array}$ & $\begin{array}{c}\text { Fiber } \\
(\%)\end{array}$ \\
\hline Reference & 1000 & 2500 & 2500 & 610 & 0 \\
PP fiber & 1000 & 2500 & 2500 & 610 & $1 \%$ \\
HMPE fiber & 1000 & 2500 & 2500 & 610 & $1 \%$ \\
\hline
\end{tabular}




\section{Table 4}

PP fiber and HMPE fiber properties

\begin{tabular}{|c|c|c|c|c|}
\hline Fiber & $\begin{array}{c}\text { Density } \\
\left(\mathrm{g} / \mathrm{cm}^{3}\right)\end{array}$ & $\begin{array}{c}\text { Tensile strength } \\
(\mathrm{MPa})\end{array}$ & $\begin{array}{c}\text { Modulus of elasticity } \\
(\mathrm{GPa})\end{array}$ & $\begin{array}{l}\text { Stretching } \\
(\%)\end{array}$ \\
\hline PP fiber & 0.94 & 41.4 & 1.55 & $15-25$ \\
\hline HMPE fiber & 0.91 & $3,000.0$ & 132.00 & 3.5 \\
\hline
\end{tabular}

for 30 seconds. One day after the mixture procedure, the samples were removed from the molds and introduced to a curing chamber for 7 days.

Table 4 shows some properties, provided by the manufacturers, of PP and HMPE fibers. Both fibers had a length of $10 \mathrm{~mm}$. The diameter and surface aspect of PP and HMPE fibers were investigated using scanning electron microscopy (SEM). Thermogravimetric analysis (TGA) was conduct for both PP and HMPE fibers in air atmosphere with a temperature range from $50{ }^{\circ} \mathrm{C}$ to $400{ }^{\circ} \mathrm{C}$, to asset the stability and decomposition of the fibers.

Thermal conductivity of the concrete samples with dimensions $300 \mathrm{~mm} \times 300 \mathrm{~mm} \times 30 \mathrm{~mm}$, was measured using the equipment HFM 436/3/1 Lambda (NETZSCH-Gerätebau GmbH, Germany) at a mean temperature of $30^{\circ} \mathrm{C}$. To evaluate the thermal expansion was used the equipment DIL 402 PC (NETZSCHGerätebau $\mathrm{GmbH}$, Germany). For this experiment, three cylindrical body samples with $10 \mathrm{~mm}$ diameter and $25 \mathrm{~mm}$ length were made for each concrete composition. Since there isn't standard practice for making these specimens, they were made using the equipment manufacturer specifications. The samples were heated from room temperature to $200{ }^{\circ} \mathrm{C}$ and the length variations were automatically computed. Compression strength after heating was measured using cylindrical body samples with $100 \mathrm{~mm}$ diameter and $200 \mathrm{~mm}$ length. The samples were heated from room temperature to $200{ }^{\circ} \mathrm{C}$ for 1 hour before the tests.

(A)

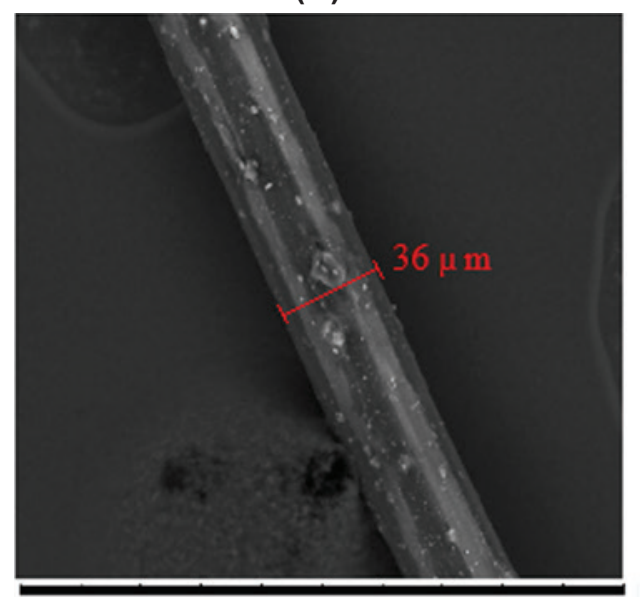

$200 \mu \mathrm{m}$

x 500

TM3000_4096 - CEFET-MG-DET
After air cooling, these samples went through a compressive strength test.

\section{Results and discussions}

\subsection{Scanning electron microscopy}

Figure 1 shows SEM images of PP fiber (Figure 1a) and HMPE fiber (Figure $1 b$ ) with a magnification of 500x.

Trough SEM images analysis it was possible to determine both fibers diameter. PP fiber and HMPE fiber diameter were measured to $20 \mu \mathrm{m}$ and $36 \mu \mathrm{m}$ respectively. The fibers exhibited very distinct surfaces. PP fibers presented a rough and solid surface while HMPE fibers shown a smoother surface and apparently composed of aligned strings of material.

\subsection{Thermogravimetric analysis}

The thermogravimetric analysis of PP and HMPE fibers are presented in figure 2. It was not observed mass loss until $200{ }^{\circ} \mathrm{C}$ for both fibers, at that point PP fibers started to lose its mass due to the decomposition of the hydrocarbon chain and formation of volatile compounds like $\mathrm{H}_{2} \mathrm{O}$ and $\mathrm{CO}_{2}$. The HMPE started its decomposition almost $50{ }^{\circ} \mathrm{C}$ after PP fiber, which implies better thermal stability for HMPE fibers. This higher thermal stability comes from
(B)

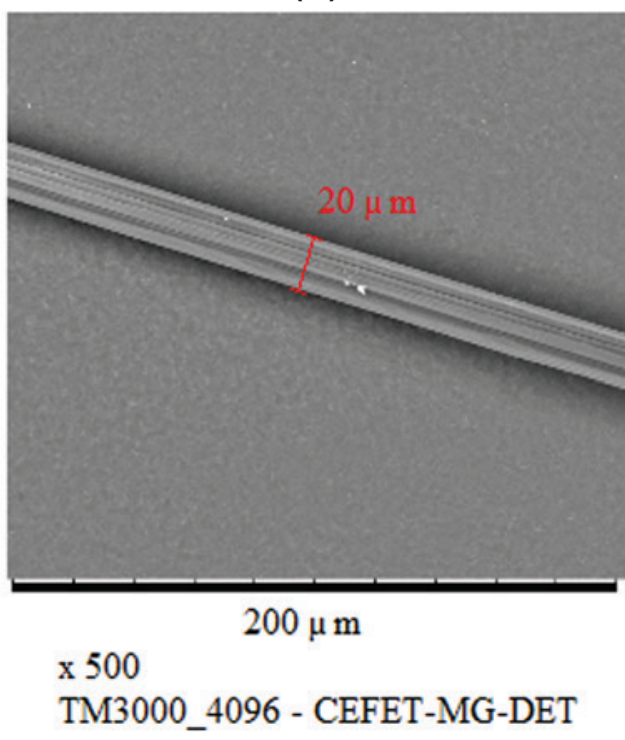

\section{Figure 1}

SEM images (magnification: 500x) of PP fiber (a) and HMPE fiber (b) 


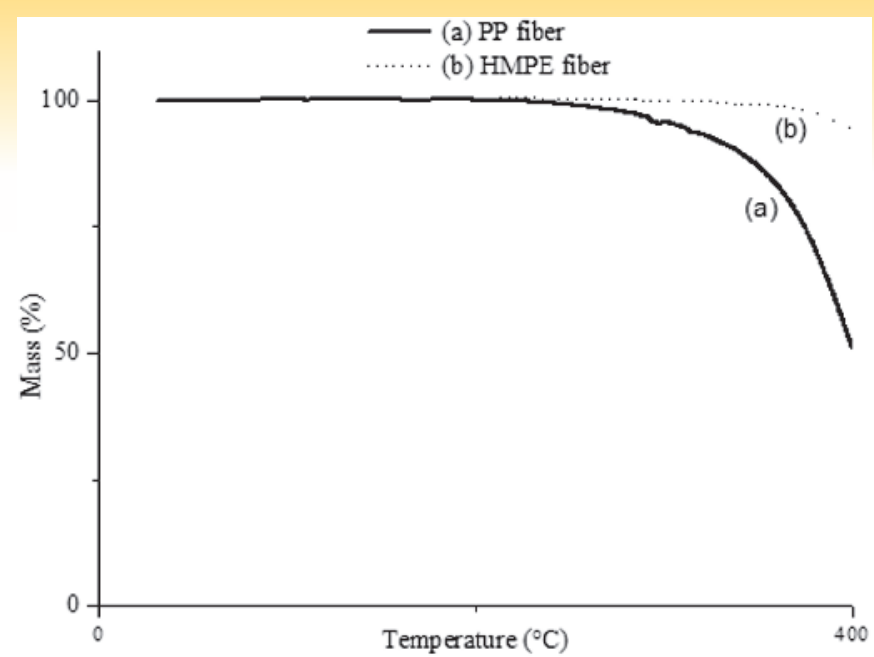

Figure 2

Thermogravimetric analysis of PP fiber and HMPE fiber

the bigger molecular mass of the HMPE fiber in comparison with PP fibers.

\subsection{Thermal conductivity}

Figure 3 presents the average values and standard deviation for the thermal conductivity coefficient of each concrete mixture. The reference concrete average value was $0.44 \mathrm{~W} / \mathrm{mK}$ in the temperature range studied $\left(20^{\circ} \mathrm{C}\right.$ to $\left.40^{\circ} \mathrm{C}\right)$. This value is within the normal range for concrete with a density similar to the one studied in this work $[15,16]$. The PP fiber reinforced concrete exhibited a lower value of thermal conductivity than HMPE fiber reinforced concrete, $0.37 \mathrm{~W} / \mathrm{mK}$ and $0.49 \mathrm{~W} / \mathrm{mK}$ respectively.

Considering the mean values and the standard deviations of thermal conductivity coefficient exhibited by the samples of reference concrete and fiber reinforced concrete, it is only possible to say that the addition of HMPE fibers produced concrete with higher thermal conductivity coefficient than the addition of PP fibers. Considering that PP and HMPE fibers have very similar chemical composition $\left[\left(\mathrm{C}_{3} \mathrm{H}_{6}\right)_{x}\right.$ and $\left(\mathrm{C}_{2} \mathrm{H}_{4}\right)_{y}$, respectively], it is possible to affirm that the change in thermal conductivity coefficient of the concrete reinforce

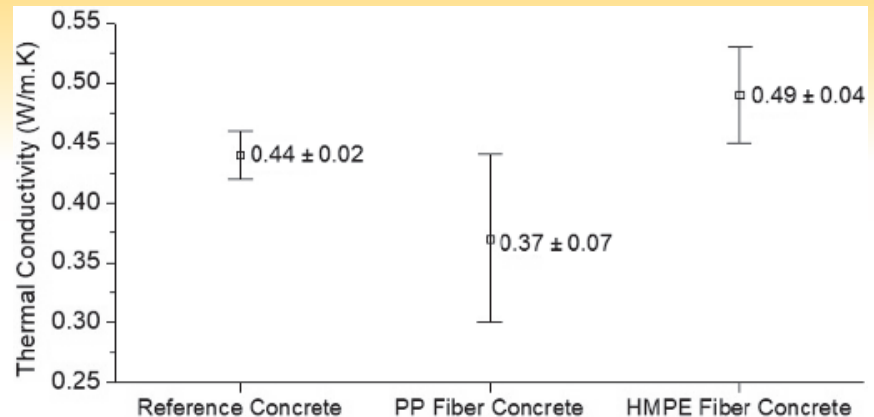

\section{Figure 3}

Thermal conductivity coefficient to the reference concrete and concrete reinforced with fibers

with these two types of fiber comes from physical and structural differences in the composite material. This could be due to the rigid structure and high elasticity modulus of the HMPE material, which could create paths inside the material with fewer discontinuities, causing the rise of the thermal conductivity.

A statistical analysis of variance (ANOVA) was made to further investigate the relationship between the mean values of thermal conductivity coefficient observed for the reference concrete and both fibers reinforced concrete. The alpha level was defined as 0.05 , and for that reason, $\mathrm{p}$-values less than 0.05 implies that the results are significant. The tests showed conclusively that between the reference concrete and PP fiber concrete, there was no significant difference in the mean values of the thermal conductivity coefficient since the $p$-value found was 0.13 . The same was concluded for the reference concrete and HMPE fiber concrete, with a p-value equal to 0.12. When PP fiber concrete was compared to HMPE fiber concrete, the ANOVA showed that HMPE thermal conductivity coefficient was in fact, higher than PP fiber concrete coefficient, with a p-value equal to 0.048 . All the results obtained through ANOVA are presented in Table 5.

\subsection{Thermal expansion}

Figure 4 shows the thermal deformation behavior of reference concrete, concrete with PP fibers and concrete with HMPE fibers. The retraction observed for every concrete mixture studied until the temperature was around $150{ }^{\circ} \mathrm{C}$, is due to concrete loss of water. All the mixtures showed a similar behavior until $100^{\circ} \mathrm{C}$. After

\section{Table 5}

Statistical analysis of variance (ANOVA, $\mathrm{P}<0.05$ ) for thermal conductivity coefficient, between reference concrete (Ref.), PP fiber concrete (PP) and HMPE fiber concrete (HMPE)

\begin{tabular}{|c|c|c|c|c|c|c|c|}
\hline & Source of variation & SS & df & MS & $\mathbf{F}$ & P-value & F crit \\
\hline Ref. & Between groups & 0.008 & 1 & 0.008 & 3.482 & 0.135 & 7.709 \\
\hline$x$ & Within groups & 0.009 & 4 & 0.002 & - & - & - \\
\hline PP & Total & 0.017 & 5 & - & - & - & - \\
\hline Ref. & Between groups & 0.004 & 1 & 0.004 & 3.750 & 0.125 & 7.709 \\
\hline$x$ & Within groups & 0.004 & 4 & 0.001 & - & - & - \\
\hline HMPE & Total & 0.007 & 5 & - & - & - & - \\
\hline PP & Between groups & 0.023 & 1 & 0.023 & 7.823 & 0.049 & 7.709 \\
\hline$x$ & Within groups & 0.012 & 4 & 0.003 & - & - & - \\
\hline HMPE & Total & 0.034 & 5 & - & - & - & - \\
\hline Ref. & Between groups & 0.023 & 2 & 0.011 & 5.556 & 0.043 & 5.143 \\
\hline $\begin{array}{c}x \\
\text { PP }\end{array}$ & Within groups & 0.012 & 6 & 0.002 & - & - & - \\
\hline $\begin{array}{c}\mathrm{x} \\
\mathrm{HMPE}\end{array}$ & Total & 0.035 & 8 & - & - & - & - \\
\hline
\end{tabular}




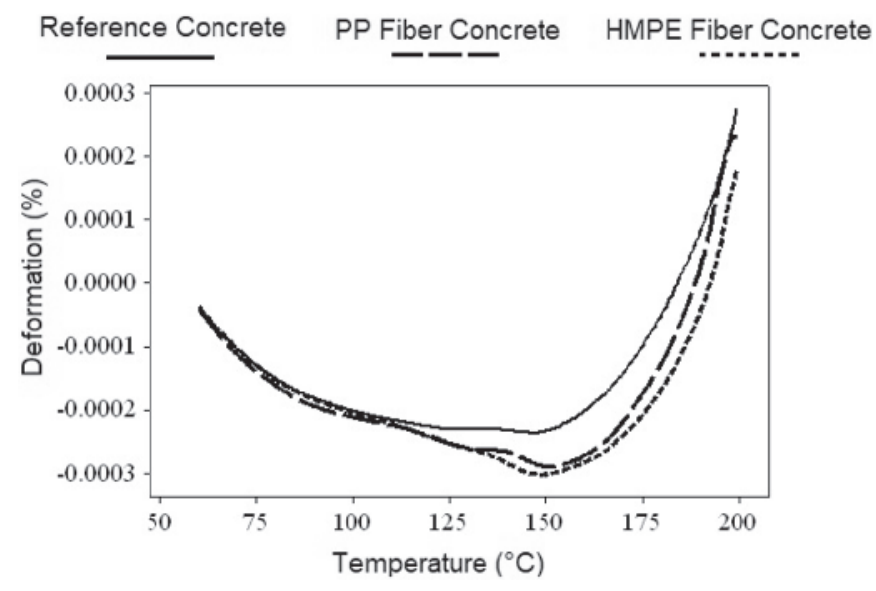

\section{Figure 4}

Thermal expansion of the reference concrete, concrete with polypropylene fiber and concrete with HMPE fiber

that point, both PP fiber concrete and HMPE fiber concrete presented less deformation than reference concrete for any temperature point until around $185^{\circ} \mathrm{C}$ where the deformation behavior of PP fiber concrete approximated to the behavior of the reference concrete. At that point, it is safe to conclude that the temperature was enough to make the PP more malleable, and by so, the PP fiber concrete lost its reinforcement due to the addition of fibers. Since the HMPE fibers were noted to keep its chemical structure at a higher temperature than the PP fibers, the HMPE fibers concrete showed less deformation than the reference and PP fiber concrete even after $185^{\circ} \mathrm{C}$. The presence of fibers in the concrete reduces the expansion of the material, because the fibers act as a reinforcement of the matrix, absorbing part of the deformation energy.

\section{Table 6}

Coefficients of thermal expansion

\begin{tabular}{cc}
\hline Concrete composition & $\begin{array}{c}\text { Coefficients of thermal } \\
\text { expansion }(10-6 / \mathrm{K})\end{array}$ \\
\hline Reference & 17.67 \\
PP fiber & 16.81 \\
HMPE fiber & 15.90 \\
\hline
\end{tabular}

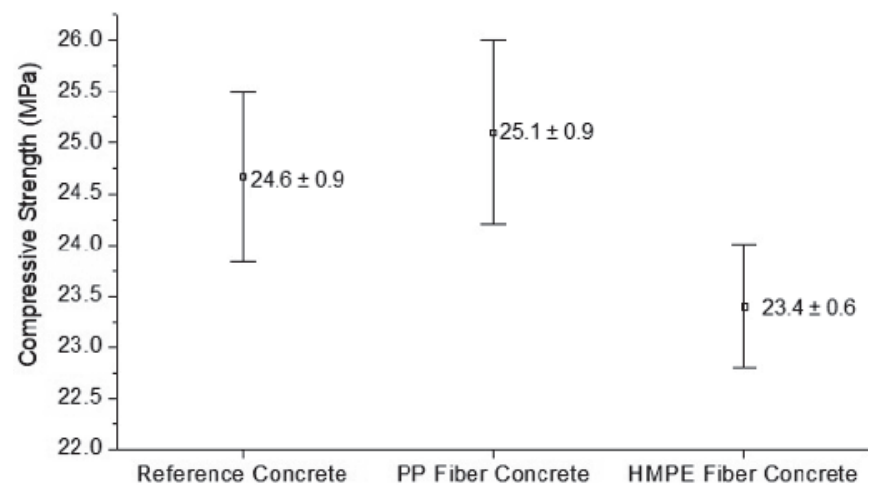

\section{Figure 5}

Compressive strength of the reference concrete and fiber reinforced concrete after exposure to a temperature of $200^{\circ} \mathrm{C}$

Table 6 shows the coefficients of linear thermal expansion $(\alpha)$ to the same reference temperature $\left(140^{\circ} \mathrm{C}\right)$ found for each mix design studied. The values found are consistent with the ones found in the literature for the coefficient of linear thermal expansion of concrete $[17,18]$. There was a reduction in the coefficient of thermal expansion of both fibers concrete in comparison with the reference concrete. For the PP fibers concrete, this reduction was around $4.8 \%$, and to the HMPE fibers concrete, this reduction was around $9.9 \%$.

The HMPE fibers concrete had a coefficient of linear thermal expansion smaller than the PP fibers concrete because the HMPE is more rigid than PP. The average tensile modulus for PP is 1.35 $\mathrm{GPa}$ while the HMPE has an average modulus of $120.50 \mathrm{GPa}$.

\subsection{Compressive strength after exposure to $200^{\circ} \mathrm{C}$}

Figure 5 shows the mean values and standard deviation for the compressive strength test after the specimens have been exposed to a temperature of $200^{\circ} \mathrm{C}$ during one hour in an oven. The reference concrete presented $24.6 \pm 0.9 \mathrm{MPa}$ of compressive strength, very close to the design fck of $25 \mathrm{MPa}$, while the fiber reinforced concrete exhibited $25.1 \pm 0.9 \mathrm{MPa}$ for the sample with PP fiber and $23.4 \pm 0.6 \mathrm{MPa}$ for the sample with HMPE fiber

Considering the analysis of variance presented in Table 7 (ANOVA, $\alpha=0.05$ ) the addition of fibers did not significantly affect the

\section{Table 7}

Statistical analysis of variance (ANOVA, $\mathrm{p}<0.05$ ) for compressive strength, between reference concrete (Ref.), PP fiber concrete (PP) and HMPE fiber concrete (HMPE)

\begin{tabular}{cccccccc}
\hline & Source of variation & SS & df & MS & F & P-value & F crit \\
\hline Ref. & Between groups & 4.580 & 2 & 2.290 & 3.470 & 0.100 & 5.143 \\
X & Within groups & 3.960 & 6 & 0.660 & - & - & - \\
X & Total & 8.540 & 8 & - & - & - \\
HMPE & & 4.335 & 1.000 & 4.335 & 7.700 & 0.050 \\
\hline PP & Between groups & 2.340 & 4.000 & 0.585 & - & - & - \\
X & Within groups & 6.675 & 5.000 & - & - & - \\
HMPE & Total & & & & - \\
\hline
\end{tabular}


compressive strength, when PP fiber, HMPE fiber, and reference concrete were compared. The analysis using the values of compressive strength exhibited a $p$-value of 0.10 , which is higher than the limit to consider these values statistically different. Although, when comparing just the PP fiber and HMPE fiber reinforced concrete, it was observed that concrete with addition of PP fibers presented statistically significant higher compressive strength than the concrete reinforced with HMPE fibers, with a p-value of 0.05 .

The reason for that behavior could lie in the modulus of elasticity of the PP and HMPE (1.35 GPa and $132.00 \mathrm{GPa}$, respectively). The lower modulus of elasticity of the PP fiber means that this reinforcement could easily absorb the early deformations and fractures that lead to the concrete sample rupture, while the same wouldn't occur, or, occur with less intensity, in the concrete reinforced with a higher modulus of elasticity material, such as HMPE. It is also possible that this decrease in the compressive strength between the PP fibers reinforced concrete and HMPE fiber reinforced concrete is due to the difference in the diameter of those fibers. The smaller diameter of the HMPE fiber results in more interfacial transition zone area between the fibers and cement paste, which could lead to a lower compressive strength.

\section{Conclusions}

Due to higher molecular mass, the HMPE fiber showed better thermal stability than the PP fiber.

The addition of HMPE fibers to concrete increased the thermal conductivity coefficient when compared with concrete reinforced with PP fibers. This could be explained by the rigid structure of HMPE fibers, resulting in paths inside the concrete with fewer discontinuities when compared with the addition of PP fibers.

The addition of PP fiber and HMPE were efficient to reduce thermal expansion of concrete, but HMPE showed better results keeping the improvements in higher temperatures. The HMPE fibers concrete had a coefficient of linear thermal expansion smaller than the PP fibers concrete because the HMPE is more rigid than PP.

The addition of PP fibers and HMPE fibers, when compared with the reference concrete, did not affect the compressive strength after exposure to a temperature of $200{ }^{\circ} \mathrm{C}$. However, the HMPE fiber concrete showed a decrease in compressive strength in that condition when compared to the just to the PP concrete, probably due to the increment in discontinuities. This behavior could be associated with the diameter of the fibers. The HMPE presented a significantly smaller diameter than the PP fiber, resulting in the more interfacial transition zone between HMPE fiber and concrete, which are usually weak points in concrete.

\section{Acknowledgments}

The authors of this paper wish to thank the support provided by POSMAT (Mestrado em Engenharia de Materiais), CAPES (Coordenação de Aperfeiçoamento de Pessoal de Nível Superior) and CEFET-MG (Federal Center for Technological Education of Minas Gerais).

\section{References}

[1] MORAVIA, W. G., GUMIERI, A. G., VASCONCELOS, W. L., Efficiency Factor and Modulus of Elasticity of Lightweight
Concrete with Expanded Clay Aggregate. Ibracon Structures and Materials Journal, v.3, n.2, p.195-204, 2010. CONDIT, C. W. The First Reinforced-Concrete Skyscraper: The Ingalls Building in Cincinnati and Its Place in Structural History. Technology and Culture, v.9, n.1, p.1-33, 1968.

[3] DOMSKI, J., KATZER, J., ZAKRZEWSKI, M., PONIKIEWSKY, T. Comparison of the mechanical characteristics of engineered and waste steel fiber used as reinforcement for concrete. Journal of Cleaner Production, v.158, p.18-28, 2017.

[4] DÜĞENCI, O., HAKTANIR, T., ALTUN, F. Experimental research for the effect of high temperature on the mechanical properties of steel fiber-reinforced concrete. Construction and Building Materials, v.75, p.82-88, 2015.

[5] AFROUGHSABET, V., OZBAKKALOGLU, T. Mechanical and durability properties of high-strength concrete containing steel and polypropylene fibers. Construction and Building Materials, v.94, p73-82, 2015.

[6] TIBERTI, G., MINELLI, F., PLIZZARI, G. Cracking behavior in reinforced concrete members with steel fibers: A comprehensive experimental study. Cement and Concrete Research, v.68, p.24-34, 2015.

CAGGIANO, A., GAMBARELLI, S., MARTINELLI, E., NISTICOे, N., PEPE, M. Experimental characterization of the post-cracking response in Hybrid Steel/Polypropylene Fiber-Reinforced Concrete. Construction and Building Materials, v.125, p.1035-1043, 2016.

[8] AKÇA, K. R., ÇAKIR, O., IPEK, M. Properties of polypropylene fiber reinforced concrete using recycled aggregates. Construction and Building Materials. v.98, p.620-630, 2015.

[9] LI, J. J., NIU, J. G., WAN, C. J., JIN, B., YIN, Y. L. Investigation on mechanical properties and microstructure of high performance polypropylene fiber reinforced lightweight aggregate concrete. Construction and Building Materials, v.118, p.27-35, 2016.

[10] BUNSELL, A. R. Handbook of tensile properties of textile and technical fibres. In: VLASBLOM, M. P., VAN DINGENEN, J. L J.The manufacture, properties and applications of high strength, high modulus polyethylene fibers. 1.ed. Woodhead Publishing, 2009. cap.13, p.437-485.

[11] SERRANO, R., COBO, A., PRIETO, M. I., GONZÁlES, $M$. N. Analysis of fire resistance of concrete with polypropylene and steel fibers. Construction and Building Materials, v.122, p.302-309, 2016.

KODUR, V. K. R., BHATT, P. P., A numerical approach for modeling response of fiber reinforced polymer strengthened concrete slabs exposed to fire. Composite Structures, v.187, p.226-240, 2018.

[13] HUMEUA, C., DAVIES, P., SMEETS, P., ENGELS, T. A. P., GOVAERT, L.E., VLASBLOM, M., JACQUEMIN, F., Tension fatigue failure prediction for HMPE fibre Hopes. Polymer Testing, v.65, p.497-504, 2018.

[14] YUSHUN, L., JINHAI, Z., HAIXIAO, L., PENGFEI, X., LINLU, G. A study of the creep-rupture behavior of HMPE ropes using viscoelastic-viscoplastic-viscodamage modeling. Ocean Engineering, v.162, p.43-54, 2018. 
[15] UYSAL, H., DEMIRBOGA, R., SAHIN, R., GUL, R. The effects of different cement dosages, slumps and pumice aggregate ratios on the thermal conductivity and density of concrete. Cement and Concrete Research, v.34, p.845-848, 2004.

[16] DEMIRBOGA, R., GUL, R. The effects of expanded perlite aggregate, silica, fume and fly ash on the thermal conductivity of lightweight concrete. Cement and Concrete Research, v.33, p.723-727, 2003.

[17] KADA, H., LACHEMI, M., PETROV, N., BONNEAU, O., AITCIN, P. C. Determination of the coefficient of thermal expansion of high performance concrete from initial setting. Materials and Structures, v.35, p.35-41, 2002.

[18] KODUR, V. K. R., SULTAN, M. A. Effect of Temperature on Thermal Properties of High-Strength Concrete. Journal of Materials in Civil Engineering, v.15, p.101-107, 2003. 